\title{
A PREDICTIVE MODEL FOR TRAVEL TIMES ON TWO-LANE STATE HIGHWAYS
}

SEPTEMBER $1970-$ NUMBER 19
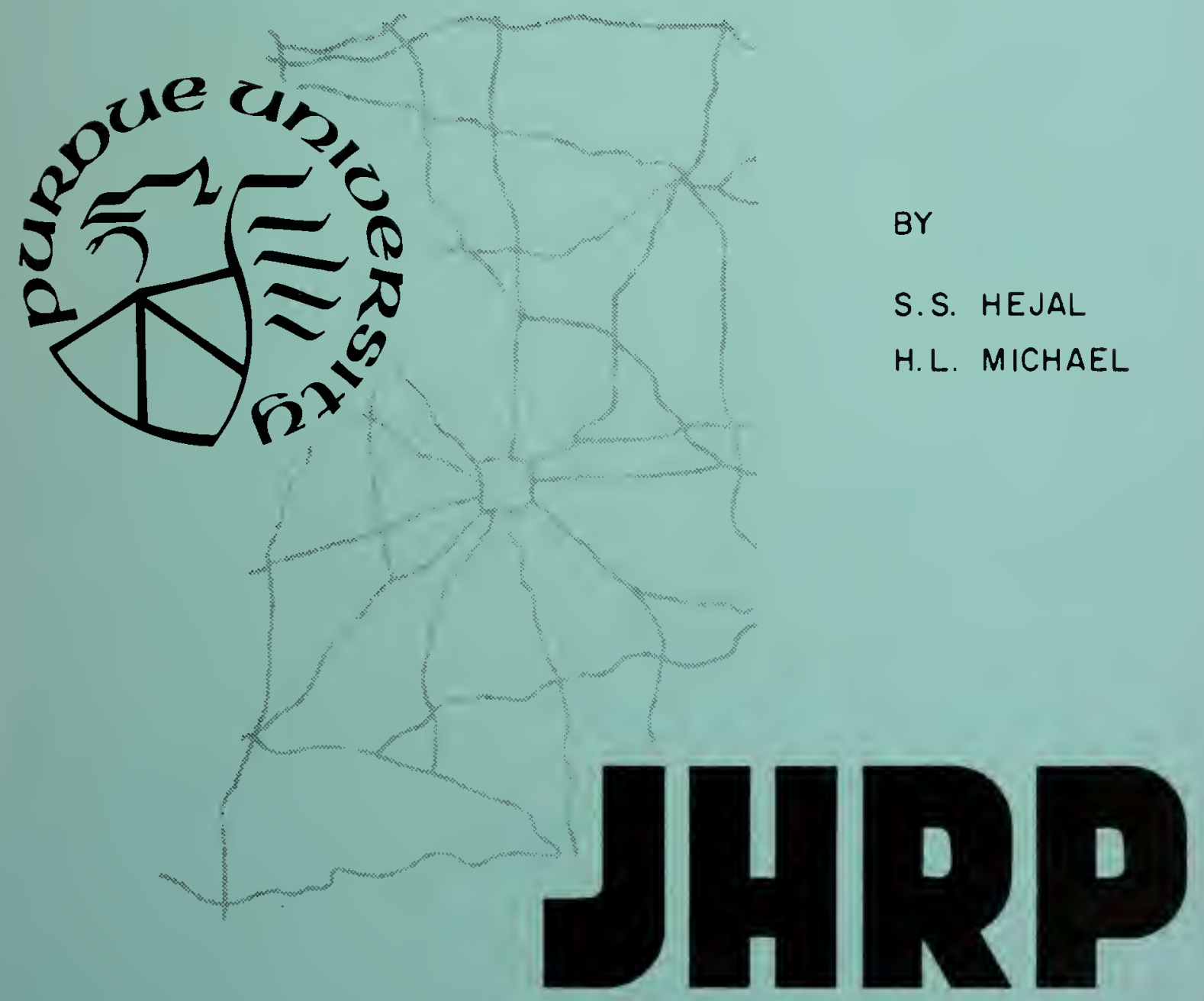

JOINT HIGHWAY RESEARCH PROJECT PURDUE UNIVERSITY AND

INDIANA STATE HIGHWAY COMMISSION 


\section{A FREOTCWTON RODEC FOE TRMVAL TITHS}

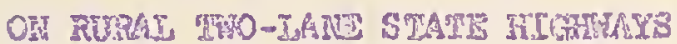

10:

J. S. Malumbing mirector

Joitit Irighway Resicosch Project.

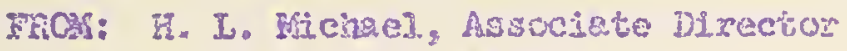
Joint Highray Research Froject
Seqtenter 15,1970

rile No.: $3-4-4$

Hroject $1 \mathrm{HO}: \mathrm{C}-36-73 \mathrm{D}$

The attached Procrens Report titied "if Prodicton Model for Travel.

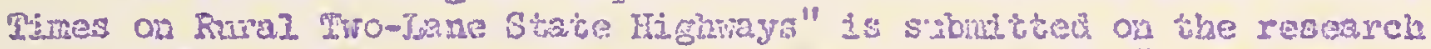
project "Priority Programing Pos Highny Constinction". The Report has

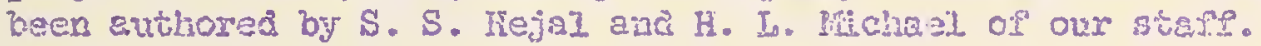

The phase of the s'aseareh zeported hare is concerned with the

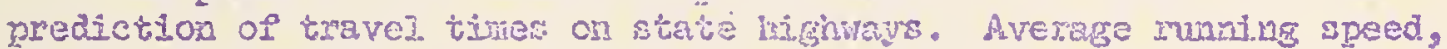
as can be obtained ixcm travel time, is an important factor in evaluath

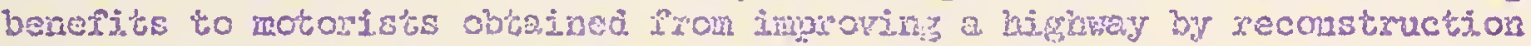
or resurfacing and should be evaluated in pritorty prograsming procedures.

The model deveioped vas founa to be a very gooc means cif predfothng

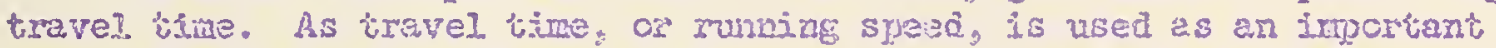
measure oi the quality of service provided by a bigibry and in ramy trancportition and trorfic engineering studes, the resuits of this phsse of the project ase presented sewarately in order to promote earyy applicetion of the rindings.

The repor'c, less Appaadiz F, is also plinmed for subrision as a Technical faper to irapte Engineering magezing. Action, therefore, is also requested on epproval ar such pubitcation.

Respectouliy submitied,

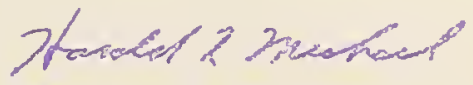

Tivald I. IAichol

fissociatse Director

\section{IIIS:MS}
ce: F. I. Ashbaucher
W. L. Dolch
II. H. Goetz
I. I. Greces
M. J. Gutzwizier
G. K. HEIIock
PI. E. Harr
R. H。 Herrell
V. F. Hay"vay
M. I. Hayes

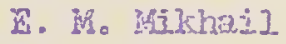
R. D. MIIes

C. F. Scholer

A. B. Scott

W. I. Speucer

H. R. J. Walsh

i. B. Hoods

E. J. Joder 


\section{Frogess Feport}

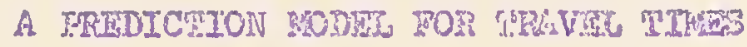

OH RUALI TWO-TANR STRTI HIGHAYS

by

SqLim S. Heizi.

Gracuate Instruchoz iñ Iesenroh

and

Hotold I. Hicher

Associato Director

Joint Elightay heseareh project

Tize Iso: $3-4-4$

Froject iro: C-3E-"i3]

Puroive Unjversjicy

Iafayetio, Indizus

September 15,1970 
Digitized by the Internet Archive in 2011 with funding from

LYRASIS members and Sloan Foundation; Indiana Department of Transportation 


\section{ABSTRACT}

Predicting travel time on inighrys is essential in evaluating the Ievel of service, the adequacy of the lighriy system, zaed user costs, and the ragnitude of improvenent needed. Daternining the expects of factors such as trafric, geonetric conditions and pavenent structural conditions on travel time on 'wo lane rural highrays was the task of this investigetion.

A stratified semple of 120 highray sections or Indione rural state highrays was selected and travel time tos measurea by the averege car method. Several mus in both directjons were made to obtsin representative average ruming times. Paraneters such as trafic rolumes, whth of prvenent, etc. veje reesured; while other verjables describing rovdway characteristics, such as terrain, length of no passing zones, etc vere cbtained from the zecoras of the suficiency imventory of minal state highways. Ten such variables were used in cata analyais.

The everge running speed was the deperdent ranjoble in the stepwise Inear regression analysis used to incerpyet travel time as a funtion of physicaz and traffic roadray conditions. A notel contuining only six. independent variebles (traffic volume, trarfic interrupions per mile, wath os pavement, stopping sight aistauce restrictions, eligumeat factor and restricted pessing sifht distance) predicted muning speeds with a high degree of accuracy, $R^{2}=.903$ and standara error of estimate of $1.876 \mathrm{mph}$. The model Fas them tested, exemined for varjation and compared with speed and yolume relationslings suggested by the Highway Capacily Manual. 
A IREDTCITON PDDEI, FOR TRLVTS TIMES

ON RURA, TWO-LANE STAIT HECHWAYS

\section{Intixodistion}

Traveltire is an essential paratieter in evaluating the level of service provided by a highway facility, the adequacy of a bighway systom, rad-user costs, and the wamitude of improvements needed. Quantifying the effects of traffic and roadwy physical condjitions on travel time, therepore, would not oniy permit better extinates or traval time but also rould provide a better evaluation of whe level of sarvice, better esinates of roa user costs and an inportunt tool usetul in decenining the cost effectiveness of various inpovement projects.

Developing a model to estlmate travel tinge on two lane runal highweys was the task of the research investigation reported here. The effects of factors such a. tratefic, geowetric features and pavenent structura I condition were evaluated. Irafic conditionis included vehicular volumes, truck volumes ane trafic interaptions. Geometrac features consisted of pavement wiaths, shoulder width, hoxirchtal and vertical alifumenti and adequacy of sight distance. Fevemeat struttural condition was measurad by the quality of the riding suriace. For a sanole or highray sections, travel time was neasured in the rield while the possible affecting factors were obtained from current highway inveutory recorts of the Indiana State Highway Comission.

For the travel tine mensurenente, two busic methods vere considered:

1. Ticense Piate Method

2. Average Car Mothod

Examination of these nethoos revealed, however, that the liceuse plate method had two inherent disaovaniagas: 
1. The tine and manporex required to concuct studies on low volume roads would be high.

2. A large variane in sampled travel time was found for one Dilot test: section, due to large variations in the speed of disferent drivers.

As the objectives of this study rexe neasuremeat of the adeguag of a highmay sectica and its level of service, the variabiltty of speeds by different operators in drivine orer it was of Iltile concern.

The average car method did not possess these disadvantages and it was the method selecter.

The test sections rere selected from ihe Iuventory Records of the Indiana State Hghway Commision. Eacin teste secion was o. Iogical, homogenems roid section begiming and enuing at well defined points, such as councy lines, hishrey junctions, cith limits, changes in roadway and pavement reatures, bridges, etc. Furthermore, many charkcteristjcs of such sections were reported in Indian's inventory records.

\section{Selection of the Stuov Sarnte}

A stratilied semple of 220 test sectims was selectod from the state of Indiana with subsamise of 20 sections in each of the six hightrag districts. A ride range of values for eech of the peraingters to be

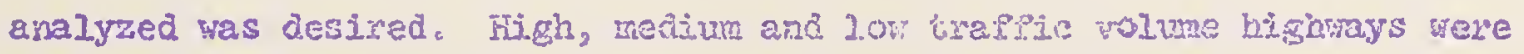
chosen and sections with pavement withe renging from 3.6 to 28 feet were selected; these are two examples of the stratification exercised to insure covernge over a. range or useiul valizes. A sample size or 120 fas utilized to insure an adequate nuber of olservations. 
A highway section to be selected for the semple had to meet the follavias requixements:

1. Incated on a ruraI tro-Iane state bighway,

2. Free of construction and maintemance operations when the travel time runs vere coneincted,

3. Outside or incorporated areas,

4. Free of restricting speed Ijmjis due to adjecent develoynent. A Iist of the test sections selected is Given ju Appenatu B.

\section{Procedure}

Travel time ras measurea by the average car techique. The test vehicle was driven at an arezage speed of 62 mph whenever trafic and roadway conditions pernitted such speed to be safely run. Iuis speed was the free flow average speed on tivo lane bighrays in Indiang for the year 1968 (1). Poor aligunent and traffic intermptions are exarples of roadway and traffic conditions which resulted in many average Innning speeds below $62 \mathrm{mph}$. Although several sections were of $\theta$ high type design and trapric volumes vere 10\%, thus pemittins s safe comortable runuing speed abore $62 \mathrm{mph}$, the speed of the test velicle wh not allowed to exceed that value. The maximum speed Iimjt on two lane highwas in Indiana is 65 mph and probably will not be xeised for many years. Hence, a 62 mph maximum average maniag speed is the spproximate mamimu which conld be legaly obtained under the highest level of service.

The procedure for collecting the deta wes as lol.lows:

I. A safe, corfortoble speed was clriven, depending on trafifc and roadway condicions. This speea, as noted previousily, wes not allowed to exceed $62 \mathrm{~mm}$. 
2. Slow moving vehicles were nassed when conditjons perritted. The passing maneuver was the unforcel type with typical acceleration and deceleration characteristica. On bighways with high troffic volunes, a balance between vehicles passing and those nassed by the lest vehicie was achieved.

3. The travel time cos cach secticn, measured with a stop watch, was an average of several runs made in both directions. The muber of runs depended on the trapric volume. On high rolume roads, five to eigint runs were caken to obtain the average travel cime.

4. On sections which dia not berin or ena trith an intersection controliea by a stop sign or a iraffic signal, the speed of the test vehicle at the beginning or exd of the section was the safe, comportable speed allowed by the highway section and conditions.

5. On highways with very litile traficic, the recorded times of individual runs wers very close and in rany casg identical. This reflects the care that was exercised jum miag the several test runs and the alnost total absence of difrerent conditions which sffectad travel time.

\section{Analysis of Field Data}

The rollowing are the variables used in the data analyis:

1. Average Runing Speed. This is the deventent variabie in the regression analysis. It wes computed by dividing the Length of the tesi section by the rocoided travel. time. Identified as SPHED. 
2. Traffic Volume. This is the voiume or trafilc, exoressed as velicles per bour, that was manaliy couted during the test geriod a: ore representative lacation on the section. Idertified as VEH/HP.

3. Truck Yolume. This is the tiuck volume, expressed as trucks per hour, that was sirnilariy ccunted during the test perioa.

Identifiec as TRH/HR.

4. Traffic Intermpticns per liiie. A trafilc interrution was der̂jined as eitiver a stop sign, a trarfic signal, or any other irapric event for ahich a' last orembals or the traffic was required to stop on severely slow dom. Such an interimption could be lcceted at the beginning, end or anywhere on the tes's section. The total musiber of these traffic intermintions was divided by the length of the section to yield thic varlabie. Identified gs TRC/LN.

5. Width of Feivent. The ectual Hidih of theusable pavement was measured ano used as an nopendent veriable in the analysis. Identified as WIULH.

6. Shoulders Width. The sverage unth of the useble part op both shoulders was another variable used in the analysis. Identilied as SHTDR。 
7. Terrain. Three different types of terrain are commonly used to idencify the topography in Indjana - Pat, roljanb and hill.y. They were codea as $I_{2} 2$ and 3 respectively. This variable was abbieviated as MrR.

8. Stopping Eignt Distance Restrictions. The total number of locations where sight distance was below the minimum standard for the hichwy class is reported por each section in the Indians Inventory records. TP no restrictions vere present, a value of zero is recorded. The abbreviation Por this variable was S.S.D.

9. Alignment Factor. For each horzoncel curve where the degree of curvature exceeds the design standard, the excessive number of degrees ldifference between actual and maximum allowble) are totaled for substardard curves on the section. Fuis wes reported in the inventory ama was icentified by AIXGNO

10. Restricted Fussing Bight Dissance. The leagh of restricted passing sight distance, reasured by $208 g i n g$ in tenths of miles the amount of the section with a yellow barier line is also reported in the inventory. This was another independent variable used in the regression and designater as NOPASE.

13. Pavement Structural Adequacy. Parement condition for the section *⿻.s measured by the type of natntenance or construction requirements. None, minor, moderate and extensive maintenarce are coded as 3. to 4, respectively, in the inventory while resurfacing and reconstmction are coded as 5 and 6 . This integer variable was used as reoorted in the nighway inventory and abbreviaced as STRFC?. 
Variables 5 through 11 vere obtained from the records of the sufficiency inventory for rural state highvays. The values vere checked while conducting the travel time study for any exrors.

A stephise linear refression analysis was pertormed by program BISD-2R (2). The cen independent variables, with all included, produced 2 Iinear estimaing nodel with an $\mathfrak{h}^{2}$, coeffictent of detemination, of 0.907. The first six variables to be inclucled in the regression program in the model produced an $\left(R^{2}\right)$ of 0.903 . As a result, the regression model for predicting travei time as linited to the six most significant variables.

whe equation, comonly called the regression anslysis model is:

$$
Y=\beta_{0}+\beta_{1} x_{1}+\beta_{2} X_{2}+\ldots \ldots \ldots \ldots+\beta_{6} x_{6}+\epsilon
$$

where $y$ is the dependent varjable, the averege cunning speed (SPEIED); $x_{i}{ }^{\prime} s$ are the independent variabzes: $\beta_{i}$ 's are the regression coefficients estimated by the least square method by program Bip-2R; $\in$ is a random error term. The values for the model obtairea in this stuay are given in Table 1. Tue values obtained using al1 ten independent variebles are presented in Appenzix A.

\section{Regression Analysis Interoretations}

When all ten of the independent variables vere included in the Isociel, four of then fiere not significant at the $95 \%$ level:

a) Truck volume per hour, TRK/HR. This indicates thet trucks did not influence travel time significanily other than their effect in the total trappic volume. On nighways where any appreciable number of trucks was otserved, the percentage of trucks in the traffic sirean was relatively constant. It 
TEBLE 1. SUMSRYY OF REGRESSTON RDDET,

$R^{2}$ coefricient of aetemination $=.903$

Standard errom of estimate $=1.876 \mathrm{mph}$

\begin{tabular}{|c|c|c|c|c|c|}
\hline Variable & $\begin{array}{l}\text { Identifi- } \\
\text { carjon }\end{array}$ & $\begin{array}{c}\text { Co- } \\
\text { efficien } \\
\beta_{i}\end{array}$ & $\begin{array}{l}\text { Standard } \\
\text { exror }\end{array}$ & to Remove & $\begin{array}{l}\text { Range of Varlable and } \\
\text { Uni's }\end{array}$ \\
\hline Constant & - & 38.43 & -. & $\ldots$ & \\
\hline$x_{1}$ & 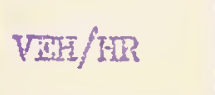 & .00133 & .00115 & $95.36 \%$ & $6-1000$, veh/hr \\
\hline$x_{2}$ & $\mathrm{mRC} / \mathrm{LaN}$ & -7.0143 & .56599 & $153.59 *$ & $0-2.5$, interrmptions/rije \\
\hline$x_{3}$ & WIDTH & 1.0452 & .10193 & $105.14^{*}$ & $3.8-30$, it \\
\hline$x_{L}$ & S.S.D. & -.3076 & .04714 & $42.58 *$ & $\begin{array}{r}0-17 \text {, number of obstructions/ } \\
\text { sect }\end{array}$ \\
\hline$x_{5}$ & ALIGNS & -.1049 & .01342 & $61.05^{*}$ & $\begin{array}{r}0-48 \text {, ercess degrees or } \\
\text { curves/sect }\end{array}$ \\
\hline$x_{6}$ & NO ZASS & -.1073 & .02709 & $39.4 .1 *$ & 0-22, tenths of railes/sect \\
\hline
\end{tabular}

* Signfricant at all levele. 
ranged between 10 to 16 percent; these were also the sections of bigh traific volumes. Ihis high correlation between truck volumes and total traficic volume on inghin volume romds could explain the non-signipicance pheromens.

b) Terrain, TwRR. Tuis emphasizes the known fact that passenger vehicles are not adversely afiected by tine teviain; furthermore no apprecjable truck volunes were obsexved on two-lane bighways on non-flat terrain.

c) Shorzder Widty, SHJuR. Jhis indicates ihat traveling speeds of passenger vehicles are not inpluenced by the widh and condition of the shoulders. It should be noted, horever, that the majority of sections with wide pavements are also the sections with vide usaide shouldeas.

d) Favement Structural Adequacy, SURFCW. This suggests that the condition of the parement does not asfect the drivers cholce of traveling speed. It aust be noted, however, that this study did not include any rad sections which had severe pavenent conditions warantirg complete resurfacing or reconstruction.

The results of the regression amalysis are conceptualiy correct. An increase in with of pavenent results in increased travel speed while an increase in trafric volume traffic intermptions, no pass restrictions, etc. reduces travel speed.

For the same highway section, higher tzaplic volumes result in larger variations in values among iadividual wus when compared with lower volumes of trafic on the sane sectica. This is a situation where 
the variance of the error term is a furction of one of the independent variables. Ihis could have been resolved by weighted regress on where more wejght is given to values at jower imafic volunes where variations are lower. While samling in the rield sol this study, more runs sere made on sections with hith trafric volunes. Inis has u similar erfect to weighting. Eathenticaliy the value $\frac{s_{i}^{2}}{n_{i}}$ was mintained relatively constunt, $\mathrm{n}_{1}$ beirg the mumer of runs or suction $i$ and $\mathrm{g}_{i}^{2}$ the estimate of the varuance on section $\dot{2}$

\section{Conciuston}

The following conclusions resulted frum the study:

1. The regression model dereloped is a siuple, efricjert way of conputing travel time on tro lane rural highways; the input: paranaters are clearly defined and many are Iisted ju the

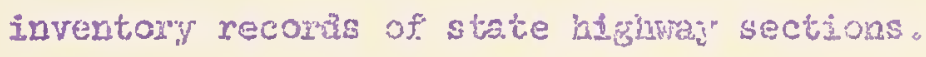

2. Ine moleI is lineax and has the alditivity proporty. or extende] rishvey Iinis, consistiar; of wore then one section, a weighted average of the vaxhbles would. produce the sume results as a welghteo average or the ruming speets on the individual sections.

3. The scope of this study is complementomy to that of the Highray Capacity Marua (3). The regression zodel concept Is a sensitjve estimator of average runiting speed on rurel two Iane highways and can be used to evaluate the level of service of highvay sections. It is easy to apyly the moded to existing bighreys where inventory data is ryesent, and one is also able to estimate the effect on level of service of factors nat evaluated by the highway capacity mamal. 
4. The estimeted average rumbing spar of a highwey section with

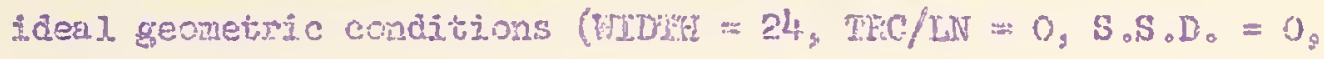
AUCHE $=0$, IMO PASS $=0$ ) aud Pree of the Influence of traffjc (VMH/HR $=0$ ) is 63.5 Digh. This vilue conforms wo the speed

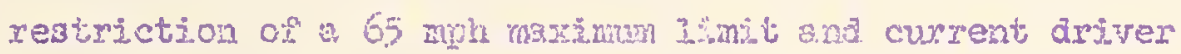
practice though higher speed could be prudutuchily achieved on such sections.

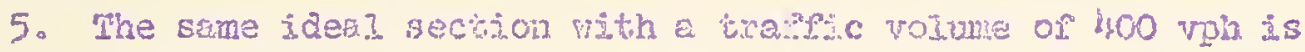
estimeted by the model to opercte at a specu of $59 \mathrm{mph}$. Fhis

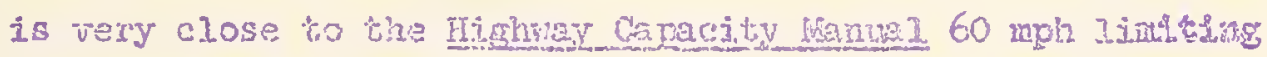
operating speed for Ievel or service a ideal two lene hightrays $(400$ vph is also the rasimm rolune for level of service 4 .

6. The increase of 50 vpli betrevin levels of seprice th and $B$ should reduce the average runizing speed by 10 mon accorajug ico the Highway Capacity Manual. The regression nodel deveioped in this study, however, produces a 5.6 moin reductios. In

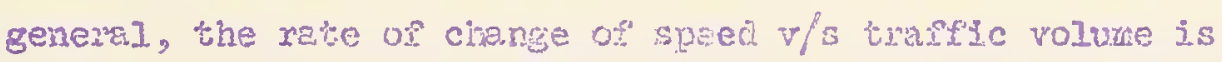
Iess using the regression model tran what the caycity wandel suggests. This suggests that the effect of volurio on zuning speed nay not be as great as estitiatec by tise capacity manua?.

7. For trowane rucal highwey, six feet peduction in the rridti

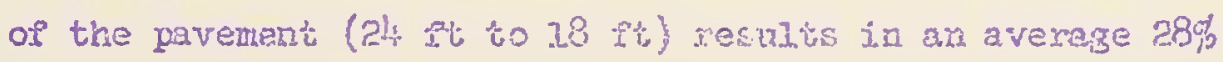
reduction in the caracity or service volute accoraing to the Firhway Capacity Manua. The sauk reduction in width mould result in 6.27 mpin decrease in ruming speeds according to the regression model. Usirg the wodel a tratic volume of 557 voh produces an equivalent speed reduction; 557 voh is also $27.8 \%$ of the capacity of such joads under ideaj corditionß 
8. Au Increase or decrease of unobstructed shoulder midin is roughzy equivalent to equal variations in paverent with, relative to ihe effect on crpacities and service rolunes according to the (apacity Menual. Examintige the coeflicients of the expanded mociel given in Mable AI ceveals that the effect ôे mobstructed shoulder wion appioximately equels the effect of pavement width on arerage ruming speeds .

\section{References}

I. Heja1, S. S., "Irepric Speed Heport No. 86," "968, Joind Higinaz Research Project. No. 37. Furcue University.

2. Dizon, W. J., BDD-Bicnedical Computer Proprans, University of Califorula Press, 1968.

3. HRB Special Report 87: Hifginay Capacitoy Mamua], 1965.

4. Oppeniander, J. C., "Variables Influencing Spotmpeed Characteristics," IRI3 Special Report $89,1966$.

5. Oppenjander, J.C., "Mutrivartate Ana3ysis of Vehicular Speeds," IMB Fecord No. $35,1963$.

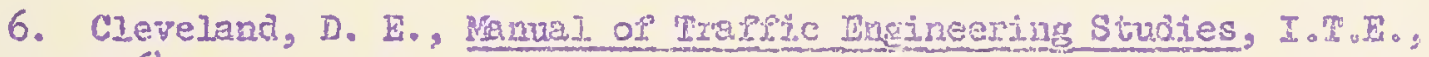
1964。

7. Draper, No R. and Ji. Smich, Appited Regressior Analysis, Wilej, 1966. 
APPENDIX 


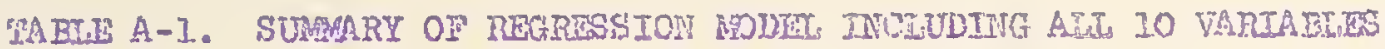

$\mathrm{R}^{2}$, coepricient of determination $=0.907$

Stancard exror of esijute : 1.8645 inpin.

\begin{tabular}{|c|c|c|c|c|}
\hline Vorriable & $\begin{array}{l}\text { Identisi- } \\
\text { cation }\end{array}$ & $\begin{array}{c}\text { Co- } \\
\text { efficient } \\
B_{i}(a)\end{array}$ & to Remove & Comeats \\
\hline $\begin{array}{c}\text { Constant } \\
x_{1} \\
x_{2} \\
x_{3} \\
x_{4} \\
x_{5} \\
x_{6}\end{array}$ & 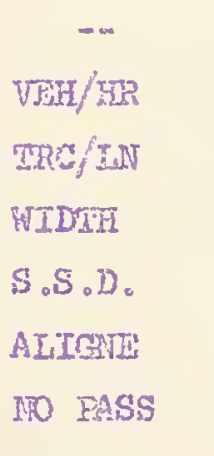 & $\begin{array}{l}39.64 \\
. .0200 \\
-7.0257 \\
1.0067 \\
-.2766 \\
-.204 .7 \\
-.1012\end{array}$ & $\begin{array}{l}47.70 \% * \\
55.65 \% * \\
80.00 \% \\
28.23 ? * \\
60.925 * \\
31.873 *\end{array}$ & $\begin{array}{l}\text { Variab?es in the regression } \\
\text { adopted by this study. }\end{array}$ \\
\hline $\begin{array}{l}x_{7} \\
x_{8} \\
x_{9} \\
x_{10}\end{array}$ & $\begin{array}{l}\text { TREYIRR } \\
\text { THRRR } \\
\text { SHLDR } \\
\text { SUREHCE }\end{array}$ & $\begin{array}{r}-.0098 \\
-.3759 \\
0.0947 \\
-.1856\end{array}$ & 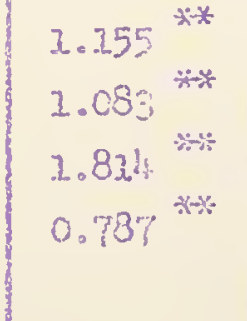 & $\begin{array}{l}\text { Additional veriables tisat } \\
\text { did not improve the } \\
\text { escinating pozer of the } \\
\text { model. }\end{array}$ \\
\hline
\end{tabular}

(a) As four more vaxiables are included, the coefficientr of the six original independent vajiables and constan in the terression are difrerent than those in Table 3.

* Significant at 95\% level.

* Not significant ai $95 \%$ Jevel. 
APPENDIX B 
Highway Test Sections Iocation, Description, and Averege Running Speed

CrewPordsville District

1. $\mathrm{SR} 18$

County: Benton

Section Begins: JCIS US 52

2. SR 25

County: rippecanoe

Section Begins: JCT SR 225

3. $S R 28$

County: Fountain

Section Begins: JCT SR 34.1

4. $S R 28$

Councy: Clinton

Section Begins: JCI US 421

5. $\mathrm{SR} 32$

County: Boone

Section Begins: Montgomery Co。 Lìne

6. 25

County: Putnam

Section Begins: JCT SR 43

7. Us 36

County: Putnan

Section Begins: Bainbridge City Irinic

8. $S R 38$

County: Tippecanoe

Section Begins: Dayror City Limit

9. $\mathrm{SR} 38$

County: Clinton

Section Begins: Tippecanoe Co. Inine

10. SR 39

County: Boone

Section Begins: JCT SR 47

11. US 4I

County: Warren

Section Begins: JCT SR 63
Speed ${ }^{*}: 58.4$ moh

Isength: 11.14 mi.

Section Inds: White Co. In

Speed: $52.8 \mathrm{mph}$

Lengtra: 2.41 wit.

Section Ends: $2.41 \mathrm{Mi}$. South

Speed : $59.8 \mathrm{mph}$

Lengtin: 4.59 mi.

Section Inds: Attica City Iimit

Speed: 61.5 raph

Iength: 8.14 mi.

Section Ends: Tipton Co. Line

Speed: 62.0 mph

Tength: $4.12 \mathrm{mi}$.

Section Finds: JCT SR 75

Speed: $58.2 \mathrm{mph}$

Length: $3.72 \mathrm{mi}$.

Section Ends: Bainbridge City Limit

Speed: 57.2 mph

Isength: $6.44 \mathrm{mil}$.

Section Ends: Hendricks Co. Ifine

Speed: $\quad 52.7 \mathrm{mph}$

Length: $4.06 \mathrm{mi}$.

Section Ends; Clinton Co. Line

Speed 55.1 mph

Iengith: $1.20 \mathrm{mi}$.

Section Inds: Nalberry City Limit

Speed: $62.0 \mathrm{mph}$

Inength: $2.40 \mathrm{mil}$.

Section Ends: $2.40 \mathrm{mi}$. North

Speed: $56.8 \mathrm{mph}$

Irengtin: 4.84 mi.

Section Ends: JCT SR 28

Heasured average muning speed as obiained in thts researeh. 
12. us 41

County: Warren

Section Begins: JCT SR 28

13. US 42

County: Fountain

Section Eegins: Attica City Linit

14. $\mathrm{SR} 43$

County: Nontgomery

Section Begins: JCT SR 234.

I5. SR 43

County: Putnara

Section Begins: Mon'gomery Co, Iilue

16. $S R 47$

County: Boone

Section Begins: hontgomery Co. Inne

17. $S R 47$

County: Boone

Section Pegins: JCT SR 39

18. SR 53

County: White

Section Begins: Tippecanoe Co. Iine

19. Us 421

County: Clinton

Section Begins: Frankfort City Limit

20. is 423

County: Boone

Section Begins: Clinton Co. tine
Speed: $\quad 49.6 \mathrm{mpl}$

Length: $1.49 \mathrm{ml}$.

Section Ends: JCT SR 55

Speed: $\quad 56.9 \mathrm{mph}$

Iength: $3.09 \mathrm{mi}$.

Section Ends: JCT SR 55

Speed: 57.7 aph

Length: $4.09 \mathrm{mi}$.

Section Finds: Putnam Co. Iine

Speed: $54.2 \mathrm{mph}$

Iength: $1.18 \mathrm{mi}$

Section Ends: JCT SR 236

Speed: $50.9 \mathrm{mph}$

Iength: $4.10 \mathrm{mi}$.

Section Eids: Thorntawn City Iimit

Speed: $61.2 \mathrm{mph}$

Iength: $8.15 \mathrm{mi}$.

Section Endis: ICI US 421

Speeã: $59.2 \mathrm{mph}$

Iength: $3.0 \mathrm{mi}$.

Section Inds: JCIS SR 18

Speed: 49.4 mph

Length: 1.27 mi.

Section Ends: 1.27 mi. North

Speed: $62.0 \mathrm{mph}$

Irength: $3.80 \mathrm{mi}$.

Section Inds: JCT SR 47

Port Hayne District

1. SR 3

County: Noble

Section Begins: JCT SR 8

2. $\operatorname{SR} 3$

County: Huntington

Section Begins: JCT SR 124,

3. SR 3

County: Wells

Section Begins: JCT SR 218
Speed: $56.0 \mathrm{mph}$

Length: $1.73 \mathrm{mi}$.

Section Inds: Avilla City limit

Speed: $59.4 \mathrm{mph}$

Length: $6.03 \mathrm{mi}$.

Section sads: Wells Co. Iine

Speed: 67.3 moh

Length: 6.03 mi.

Section Ends: Elackford Co. Lfine 
4. SR 3

County: Blackford

Section Begins: Wells Co. Iine

5. $\mathrm{SR} 5$

County: Huntingtion

Sectina Begins: JCT I 69

6. US 6

County: Noble

Section Begins: JCI SR 9

7. SR I5

County: Elkhart

Section Begins: JCT us 6

8. SR 15

Counity: Kosciusko

Section Begins: Elkhart Co. Iine

9. $\mathrm{SR} 15$

County: Wabasn

Section Begins: JCT SR 124

10. $S R 18$

County: Grant

Section Begins: JCT SR 13

11. $3 R \quad 18$

County: Grant

Section Begins: $45 \mathrm{mi}$ E. F Finion

12. SR 19

Couniy: Ellehart

Section Begins: Nappanee City Limit

13. US 31

County: Miami

Section Begins: JCI SR 218

14. Us 31

County: Miami

Section Begins: JCT SR 218

15. us 33

County: Whitley

Section Begins: Allen Co. Line

16. SR 105

County: Hunilington

Section Begins: JCT SR I24
Speed: $\quad 56.6 \mathrm{moh}$

Iength: $1.00 \mathrm{mi}$.

Section Ends: JCT SR 18

Speed: $61.5 \mathrm{mph}$

sength: $2.01 \mathrm{mil}$

Section Fnds: Warren City Iimit

Speea: $\quad 57.8$ mph

Iength: $4.68 \mathrm{mi}$.

Section Ends: Kendallville City Limit

Speed: $54.0 \mathrm{mph}$

Length: $1.05 \mathrm{mi}$.

Section Ends: Kosciusko Co. Line

Speed: 53.9 mph

Length: $2.47 \mathrm{mt}$.

Section Ends: Milford City Limit

Speed: 62.0 rago

Iength: $\quad 3.09 \mathrm{mi}$.

Section Ends: Wabesh City Limit

Speed: 5 t. 2 mph

Iength: $5.98 \mathrm{mi}$.

Section Ends: Marion City Iimit

Speed: $54.5 \mathrm{mph}$

Iength: $4.65 \mathrm{mI}$.

Section Rads: $10 \mathrm{w}$ Divided Hivy

Spsed: $61.9 \mathrm{mph}$

Length: $3.88 \mathrm{mi}$.

Secition Finds: JCI SR 119

Speex: $39.4 \mathrm{mph}$

Lengith: 1.13 riì.

Section Eads: JCT SR 218

Speed: 52.9 mph

Iength: $\quad 5.21 \mathrm{mi}$.

Section Ends: JCI SR 28

Speed: $60.0 \mathrm{mph}$

Length: $1.30 \mathrm{mi}$.

Section Ends: Churubusco City Irimit

Speed: $\quad 51.5 \mathrm{mph}$

Lengrin: $5.10 \mathrm{mi}$.

Section Ends: JCT SR 218 
17. SR 124

County: Mcisul

Section Reglns: Wabasi Co. Iine

18. $\mathrm{SR} 124$

County: Huntingtion

Section Begins: habash Co. Joine

19. SR 124

County: Hunitingtom

Section Bezins: JCT SR 3

20. SR 124

County: Weils

Section Bexias: Hun'tingron Co. Tine
Speed: $43.9 \mathrm{mph}$

Length: $5.20 \mathrm{mf}$.

Section Ends: $5.20 \mathrm{mi}$ Past

Speed: $62.0 \mathrm{mph}$

Length: $1.0 \mathrm{mi}$.

Section Inds: JCT SR 105

Speed: $\quad 55.9 \mathrm{mph}$

I.ength: $2.01 \mathrm{mi}$.

Gection Ends: Weils Co. Line

Speed: $58.3 \mathrm{mph}$

Iengih: 2.89 mi.

Section Inds: JCT SR 303

\section{Greenfield District}

1. SR 3

County: Delaware

Section Begins: JCW US 35

2. SR 3

County: Henry

Section Begins: Delakare Co. Inine

3. $\mathrm{SR} 19$

County: ripton

Section Begins: Tipton City Limit

4. SR 19

County: Hamilton

Section Begins: Cicero City Iinit

5. SR 26

County: Grant

Section Begins: JCT US 35

6. $\mathrm{SR} 26$

County: Grant

Section Begins: Feimont City Jimit

7. US 31

County: Hamilton

Sect1on Begins: JCT US 431

8. Us 31

County: Hamilton

Section Begins: JCT SR 234

9. SR 32

County: Randolph

Section Begins: Parker City Iimit

Speed: $\quad 58.5 \mathrm{mph}$

Iength: 5.61 mí.

Section Ends: Henry Co. Line

Speed: $62.0 \mathrm{mph}$

Length: $4.78 \mathrm{mi}$.

Section Ends: Divided Hwy. 4.78 kif.S

Speed: $58.9 \mathrm{mph}$

Iength: 3.77 mi.

Section Ends: hamilton Co, Line

Speeci: $\quad 57.0 \mathrm{mph}$

Leagth: 2.06 mi.

Section Fnds: Arcadia Cicy Jimit

Speed: $54.3 \mathrm{mph}$

Iength: $1.60 \mathrm{mi}$.

Section Ends: JCI SR 221

Speed: 62.0 mph

Iength: $4.84 \mathrm{mi}$.

Section Inds: JCT I 69

Speea: $53.1 \mathrm{mph}$

Lengin: J.29 mi.

Section Iruds: JCT SR 234

Speed: $57.2 \mathrm{mph}$

Iengti: $3.76 \mathrm{mi}$.

Sect1on tonds: Divided Highway

Speed: $\quad 60.6 \mathrm{mph}$

Isength: $3.61 \mathrm{mi}$.

Section Inds: Farmland Cj.ty Ijait 
10. US 35

County: Howard

Section Begins: JCT SR 19

11. US 36

County: Heary

Section Begins: Sulphur Springs City Iimit

12. Us 36

County: Mdison

Section Begins: JCT SR 38

13. US 36

County: Mison

Section Begins: JCT SR 109

14. $S R 37$

County: Jiamilton

Section Regias: JCI SR 32

15. $S R 38$

County: Madison

Section Bagins: Hamilton Co. Isine

16. $\mathrm{SR} 38$

County: Rajison

Section Begins: JCT. SR 13

17. SR 67

County: Hancock

Section Begins: JCI SR 234.

18. SR 67

County: Hancock

Section Begins: Fortvizle City Iimit

19. SR 109

County: Maison

Section Regins: JCT US 36

20. SR 221

County: Grant

Section Begins: JCT SR 26
Speed: $57.1 \mathrm{mph}$

Lengtich: $3.04 \mathrm{mf}$.

Section Ends: Greentom City Iimit

Speed: $61.8 \mathrm{mph}$

Iength: $2.46 \mathrm{mi}$.

Section Ends: Mi. Summit City

Iimit

Speed: $60.3 \mathrm{mph}$

length: $4.32 \mathrm{mi}$.

Section Ends: JCT SR 109

Speed: $58.2 \mathrm{mph}$

Iengin: 1.04 wi.

Section Ends: JCT SR I09

Speed: $53.8 \mathrm{mph}$

Iength: $1.52 \mathrm{mi}$.

Section Ends: JCT SR 238

Speed: $52.2 \mathrm{mph}$

Iength: $1.05 \mathrm{mi}$.

Section Ends: JCT SR 13

Speea: 50.4 raphs

Jength: $4.00 \mathrm{mi}$.

Section Frads: JCT I 69

Speed: $57.5 \mathrm{mph}$

Iengith: $4.00 \mathrm{mi}$.

Section Ends: Fortville City Ifmit

Speed: $61.3 \mathrm{mph}$

Length: $1.15 \mathrm{mi}$.

Section Ends: Nadison Co. Line

Speed: 51.2 moh

Length: $1.57 \mathrm{mi}$.

Section Ends: JCT SR 38

Speed: $52.9 \mathrm{raph}$

Length: $2.05 \mathrm{mi}$.

Section Ends: JCT SR 22

\section{LaPorte District}

1. $S R 2$

County: IaPorte

Section Begins: JCT US 6
Speed: $\quad 56.3 \mathrm{mph}$ Length: I.I8 mi. Section Ends: Porter $\mathrm{CO}_{\text {. Ifine }}$ 
2. Us 6

County: Porter

Section Begins: Ia Porte Co. Iine

3. US 6

County: Is Porte

Section Begins: JCT SR 39

4. $\cos 6$

County: larshal

Section Begins: Bremen City Limit

5. SR 8

County: Starke

Section Begins: Knoy City Limit.

6. SR 16

County: Newton

Section Begins: Brook City Limit

7. SR 18

County; Carroll

Section Begins: JCr US t2I

8. SR 24

County: Neriton

Section Begins: Goodlands City Iimit

9. $S R 24$

County: Newton

Section Begins: Rentlend City Iimit

10. SR 25

County: Fulton

Section Begins: Cass Co. Iine

11. Us 31

County: Fulton

Section Begins: JCT SR 110

12. US 35

County: Starke

Section Begins: JCT SR 10

13. US 35

County: Starke

Section Begins: Pulaski Co. line

14. $S R 39$

County: Carroll

Section Begins: Delphi City Limit
Speed: $59.2 \mathrm{mgh}$

Iength: $4.90 \mathrm{mi}$.

Section Ends: $4.90 \mathrm{mi}$. East

Speed: $59.0 \mathrm{mph}$

Iength: $2.27 \mathrm{mi}$.

Section Ends: JCT US 35

Speed: $57.9 \mathrm{mph}$

Length: $4.45 \mathrm{mi}$.

Section Ends: Elkhart Co. Iine

Speed: $52.9 \mathrm{mph}$

Lengtin: $4.05 \mathrm{mi}$.

Section Erds: JCT SR 23

Speed: $50.7 \mathrm{mph}$

Length: $2.63 \mathrm{mi}$.

Section Ends: JCT SR 55

Speed: $60.5 \mathrm{mph}$

Lengin: $6.05 \mathrm{mil}$.

Section Ends: Flcro, City limits

Speed: $58.8 \mathrm{mph}$

Jength: $1.08 \mathrm{mi}$.

Section Ends: Jasper Co。 Iine

Speed: $59.0 \mathrm{mph}$

Length: 5.83 roi.

Seciion finds: JCT SR 55

Speed: $61.2 \mathrm{mph}$

Iength: $2.38 \mathrm{mi}$.

Section Ends: FuIton C1ty Limit

Speed: $52.1 \mathrm{mph}$

IJength: 3.57 mis.

Section Prads: $4.50 \mathrm{mil}$. South

Speed: $61.8 \mathrm{mph}$

Length: $1.24 \mathrm{mi}$.

Section Ends: JCT SR 10

Speed: 52.5 raph

Length: $1.0 \mathrm{mi}$.

Section Juds: Bess City Limit

Speed: $62.0 \mathrm{mph}$

Iength: 2.47 mì.

Section Ends: JCT SR 18 
15. SR 53

Counity: Jasper

Section Begins: Fensselaer City init

16. SR 104.

County: St. Joseph

Section Begins: JCT SR 10

17. SR 117

County: Rarsball

Section Begins: JCT SR 10

18. US 421

County: LaPorite

Section Begins: JCT US 6

19. US 421

County: Poraski

Section Begins: JCT SR 134

20. is 421

County: White

Section Begins: Fulaski Co. Iine
Speed: $52.8 \mathrm{mph}$

Length: $4.10 \mathrm{mi}$.

Section Ends: JCT SR 16

Speed: $48.5 \mathrm{mph}$

Length: $2.12 \mathrm{mil}$.

Section Ends: Porter Co. Iine

Speed: $37.2 \mathrm{mph}$

Ientgth: 4.27 mi.

Section Finds: JCT SR 110

Speed: $57.5 \mathrm{mph}$

Length: $2.87 \mathrm{mi}$.

Section Eads: $2.87 \mathrm{mi}$.

Speed: $56.5 \mathrm{mph}$

Lengih: $1.75 \mathrm{mi}$.

Section Ends: Unite Co. Line

Speed: $57.9 \mathrm{mph}$

Length: 2.81 mi.

Section Inds: Monon City Iimit

\section{Seymour District}

1. SR 11

County: Floya

Section Begins: JCT SR 62

2. $\mathrm{SR} 37$

County: Morgan

Section Begins: Johnson Co. Iine

3. SR 37

County: Johnson

Section Begins: Mojgan Co. Line

4. SR 37

County: Johnson

Section Begins: Marion C\%。 Iine

5. SR 44

County: Johnson

Section Begins: Morgan Co. Iine

6. SR 46

County: Bartholomew

Section Begins: Brown Co. Line
Speed: $38.4 \mathrm{mph}$

Iengit: $5.72 \mathrm{mi}$.

Section Inds: Harrison Co. Line

Speed: $60.0 \mathrm{mph}$

Iength: $2.00 \mathrm{mi}$.

Section Ends: JCT SR 2.52

Speed: $58.1 \mathrm{mph}$

Iength: 0.62 mi.

Section Ends: JCT SR 144

Speed: $53.4 \mathrm{rmh}$

Iength: $2.86 \mathrm{mi}$.

Section Ends: $2.86 \mathrm{mi}$. South

Speed: $43.8 \mathrm{mph}$

Jeagih: $5.19 \mathrm{mi}$.

Section Ends: JCT SR 135

Speea: $59.6 \mathrm{mph}$

Iengith: $2.15 \mathrm{mit}$.

Section Ends: $2.15 \mathrm{mi}$. East。 
7. SR 46

County: Bartholomew

Section Begins: JCr I 65

8. Us 50

Counity: Jennings

Section Begins: No Vernon Cicy Iimit

9. us 50

County: Ripley

Section Begins: Jrnnings Co。 Line

10. SR 58

County: Jackson

Section Begins: JCT SR 258

11. SR 62

County: Harreison

Section Begins: Lanesville City Iimit

22. $S R 62$

County: Floyd

Section Begins: Harrison Co. Iine

13. $S R 62$

County: Ripley

Section Begins: JCT SR 129

14. SR 135

County: Johnson

Section Begins: JCT SR 252

15. SR 135

County: Joinson

Section Begias: JCT SR I44

16. US 150

County: Harrison

Section Begins: Palmyra City Iirit

17. Us 150

County: Floyã

Section Begins: Harsison Co. Iine

18. SR 250

County: Jacisson

Section Begias: Browastona City Iimiti

19. SR 252

County: Johnson

Section Begins: JCI SR 135

20. US 421

County: Ripley

Section Begins: JCT US 50
Speed: $54.8 \mathrm{inph}$

Length: 2.35 mi.

Section Rnds: 2.35 mit thast

Speed: 59.8 raph

Iergth: 1.92 mii.

Section Ends: JCP Co. Rd. 161.

Speed: $59.1 \mathrm{mph}$

Length: $3.88 \mathrm{mi}$.

Section Ends: Holton City Iimit

Speed: $37.9 \mathrm{mph}$

Lengtin: $4.81 \mathrm{mar}$.

Section Inds: Bartholorew Co. Line

Speed: $55.1 \mathrm{mph}$

Tength: $1.36 \mathrm{mi}$.

Section Euds: Fioya Co. Line

Speed: 54.8 mh

Jeagtin: $1.54 \mathrm{mi}$.

Section Ends; JC2 SR 17

Speed: $39.3 \mathrm{mph}$

Jength: $5.67 \mathrm{mf}$.

Section Finds: Dearborn Co. Inine

Speed: $60.5 \mathrm{mph}$

Length: 5.T5 mi.

Section Inds: Morgan Co. Iine

Speed: 56.1 mpin

Length: $8.09 \mathrm{mi}$.

Section Eads: Vion Co. Line

Speed: $60.1 \mathrm{mph}$

Iength: 4.20 mi.

Section Ends: Froyd Co. In

Speed: 57.0 mph

Iength: $1.73 \mathrm{mi}$

Section Inds:' Greenville City Limit

Speed: 45.6 mph

Lengih: $2.19 \mathrm{mi}$.

Section rands: JCT SR 39

Speed: 60.4 mph

Ijength: 1.11 mi.

Section Inds: $1.11 \mathrm{mi}$. Fast

Speed: 58.4 mph

Eength: $3.57 \mathrm{mi}$.

Section Ends: Osgood City I,imit 
I. US 41

County: Knox

Section Begins: Vincernes City Ijimit

2. SR 45

County: Drzbois

Section Begins:

3. Us 50

County: Daviess

Section Begins:

4. SR 56

County: Pike

Section Begins: JCT SR 25\%

5. $S R 56$

County: Filie

Seciton Begins: Petersuurg Cjty Iirit

6. SR 57

County: Greene

Section Regins: Newberry City Limit

7. SR 57

County: Daviess

Section Begins: Greene Co. Line

8. SR 57

County: Pike

Sect1on Begins: Daviess Co. Line

9. SR 58

County: Laviess

Section Begins: Knors Co。 Inine

10. $S R 62$

County: Spencer

Section Begins: Dale City Iinit

11. SR 62

County: Perry

Section Begins: JCT SR 37

12. SR 62

County: Crawtoro

Section Begins: Perry Co. Line
Speed: 50.9 mph

Length: $1.79 \mathrm{mi}$.

Section Inds: $1.79 \mathrm{mi}$. South

Speed: 55.6 iph

Jength: 3.88 wis.

Section Ends: Jasper City Isimit

Speed: 58.2 mph

Tength: $6.50 \mathrm{mi}$

Section Ends: 6.50 mi. Fast

Speed: 61.4 mph

Iengtin: $1.03 \mathrm{mi}$.

Section Enas: Irools Co. Lîne

Speed: $53.4 \mathrm{mph}$

Lengts: 4.08 mi.

Section Frnds: JCT SR 6I

Speed: 53.4 inph

Iength: 2.48 tai.

Section Inds: Daviess Co. Tine

Speed: $59.2 \mathrm{mph}$

Length: $2.87 \mathrm{mi}$.

Section Ends: Elnor City Limit

Speed: 53.3 mph

Length: $3.60 \mathrm{mi}$.

Section Ends: Petersburg City Ifmit

Speed: $55.2 \mathrm{mph}$

Isength: $1.60 \mathrm{mi}$.

Section Ends: Elnora City Limit

Speen: 59.0 moh

Wength: $5.09 \mathrm{mi}$.

Section Inds: JCT SR 162

Speed: $45.6 \mathrm{mph}$

Iengich: $1.01 \mathrm{mi}$.

Section trads: Crawford Co. In

Speed: $47.5 \mathrm{mph}$

Iength: $6.08 \mathrm{moj}$.

Section linds: JCT SR 66 
13. $S R 64$

County: Dubois

Section Begins:

I4. SR 64

County: Dubois

Section Begins: JCT SR 162

15. $S R 60$

County: Crawfora

Section Begins: Perry Co. Ilne

16. SR 67

County: Knox

Section Begins: JCT SR 358

17. SR 67

County: Knax

Section Begins: End Divided Hroy.

18. SR 145

County: Dubois

Section Begins: Perry Co, Iine

19. SR 257

County: Pike

Sect1on Begins: JCT SR 356

20. US 460

County: Spencer

Section Begins: Wrarrick Co. Isine
Speed: $58.9 \mathrm{mph}$

Length: $3.87 \mathrm{mil}$.

Section Ends: JCT SR 162

Speed: $57.2 \mathrm{mph}$

Iengin: $2.24 \mathrm{mi}$.

Section Inds: St. Anthony City Limit

Speed: $43.4 \mathrm{mph}$

Lengih: $1.76 \mathrm{mi}$.

Section Ends: JCT SR 62

Speed: $58.2 \mathrm{mph}$

Length: $0.76 \mathrm{mi}$.

Section Inds: Edkerdsport City Limit

Speed: $56.2 \mathrm{mph}$

length: $4.27 \mathrm{mi}$.

Section Inds: Bruceville City Iimit

Speed: $42.3 \mathrm{mph}$

Iengich: $4.52 \mathrm{mi}$.

Section Inds: Birdseye City Limit

Speed: $54.9 \mathrm{mph}$

Lengich: $5.28 \mathrm{mi}$.

Section Hnds: Daviess Co. Iine

Speed: 60.8 mph

Iength: $1.93 \mathrm{mi}$.

Section Bnds: JCT SR 45 

